\title{
Critical Success Factors for a Micro-Pension Plan: An Exploratory Study
}

\author{
Amos Gitau Njuguna \\ United States International University, P.O Box 14634-0800, Nairobi, Kenya \\ Tel: 254-20-360-6204 E-mail: amnjuguna@usiu.ac.ke
}

Received: June 18, 2012

Accepted: July 28, 2012

Online Published: October 12, 2012

doi:10.5430/ijfr.v3n4p82

URL: http://dx.doi.org/10.5430/ijfr.v3n4p82

Research was sponsored by the Retirement Benefits Authority in Kenya.

\begin{abstract}
Micro-pension plans are meant to insulate low income earners against old-age poverty. The formulation of such plans requires a delicate balance between economic viability, generation of adequate returns and customized features for the participants. This study sought to determine the pragmatic models for implementation of micro-pension plans, regulatory issues surrounding their operations, challenges to implementation and the strategies that can address the challenges. The data, collected from 1083 informal sector participants, 30 Micro-finance institutions and 20 Savings and Credit Cooperative Societies in Kenya was analyzed by use of factor analysis and visual binary approaches. The study concludes that the ideal micro-pension scheme needs to address governance, administrative, design and efficiency issues to succeed and recommends a multi-model implementation of micro-pension plans in addition to a separate set of regulations to govern the micro-pension plans.
\end{abstract}

Keywords: Micro-pension, Pension efficiency, Pension governance, Micro-pension models

\section{Introduction}

The informal sector plays an imperative role in world economies as it creates jobs, boosts entrepreneurial activity, minimizes unemployment and underemployment, alleviates poverty and contributes to economic growth (Winters, 2002; World Bank, 2006; Chen, 2007). The sector had a weighted average value of $17.2 \%$ of official GDP in 162 countries between 1999 and 2007 (Schneider, Buehn \& Montenegro, 2010). The World Bank on the other hand estimates the size of the informal labour market to be $4-6 \%$ in the high-income countries and over $50 \%$ in the low-income countries. In Kenya, the sector has grown progressively from $4.2 \%$ of the total employment in 1972 , 10.3\% in 1980, 15.2\% in 1985, 39.1\% in 1990, 53.4\% in 1994 (Ikiara \& Ndungu, 1999) and 80\% in 2011 (Economic Review, 2011).

A key policy issue in developing countries is how to get participants in the informal sector to save and plan for retirement as a result of which over $90 \%$ of the population in Sub Saharan Africa and South Asia are not covered by any pension arrangement (Keizi, 2006, 2007) due to general unemployment, low incomes, poor saving culture and above all pension arrangements that only favour workers in the formal sector (Kakwani, Sun \& Hinz, 2006).

Informal workers' characteristics that alienate them from formal pension arrangements include; their continuous change of jobs, frequent opts to self employment, temporary nature of their employment contracts, they live in remote rural areas or urban slums, they are often illiterate and unfamiliar with the concept of pensions and they have little experience of dealing with formal financial institutions (Uthira \& Manohar, 2009). Micro-pension schemes support small, regular and sustainable savings by low income earners and provide them with a regular stream of income for the old-age (Shankar, 2009; Uthira \& Manohar, 2009) and can therefore be viewed as smart forms of savings and insurance (Dullemen \& Bruijin, 2011).

Different countries have varying forms of micro-pension systems; for instance Bangladesh and India have a model operated on the Grameen principles, Chile has a government subsidized and co-sponsored scheme, China has a scheme characterized by compulsion, minimum income guarantees and micro life insurance products, Kenya has a voluntary defined contributory scheme and South Africa's informal sectors workers are covered by the public pension system (Hu \& Stewart, 2009). It is apparent that policymakers need to review success factors for different micro-pension models in use. 
Theoretical justification for micro-pension schemes and the consequent economic sustainability of micro-pensions are addressed by Hu \& Yermo (2009); Uthira \& Manohar (2009); Dullemen \& Bruijin (2011). Other studies (Keizi, 2007; Rajan, 2003; Barrientos, 2007) emphasize on the reasons for low pension coverage in the informal sector and suggestions to increase the coverage. This study adds to the empirical literature by establishing the features of a micro-pension system to cover the informal workers and provides policy recommendations on the steps that can be taken to address the challenges to the implementation of such a system in Kenya.

\section{Literature Review}

\subsection{Characteristics of the Ideal Micro-pension Scheme}

$\mathrm{Hu}$ and Stewart (2009) suggest measures to encourage contributions to the micro-pension scheme by the informal sector workers as; flexible terms for workers with regard to the contribution amounts, vesting policies and voluntary contributions; monetary incentives for participants and financial education. Additionally micro-pension schemes should ensure coverage by a high proportion of the population, have infrastructure that is supportive of mass registration, contribution collection and database management as well as flexibility of contributions and access to benefits (Uthira \& Manohar, 2009). Tradeoffs exist in the design of micro-pension schemes. For instance flexibility of contributions encourages contribution of small but frequent amounts resulting not only to lesser contributions but also high transaction costs and consequently low benefit payouts; voluntary contributions meant to encourage enrolments result to the participants not prioritizing pension contribution; high enrolment lowers administrative costs but results to diseconomies of scale in the long run and saving for the future minimizes old age poverty but lowers the amounts available for consumption today especially given that informal sector participants do not have enough means for today.

\subsection{Models for Implementation of Micro-pension Schemes}

Uthira and Manohar (2009) suggests the models that can be used to implement micro pension plans as the partnership model served by Non Governmental Organizations, banks and large industrial houses; the Grameen model with compulsory savings; the agency model where agents sell micro-pensions to clients and the Micro-agent model that is similar to multi-level marketing. Hu and Stewart (2009) further propose the utilization of existing (non pension) institutions such as post offices and micro finance institutions to offer micro pension products. With the minimal literature available, this study builds on the concepts developed by Uthira and Manohar (2009) and Hu and Stewart (2009) to explore additional models that can be used to implement micro-pension plans.

\subsection{Challenges to Implementation of Micro-Pension Plans}

\subsubsection{Demand Side Challenges}

One of the major challenges to formal micro-pension arrangements is the fact that participants already have other ways of meeting their retirement needs. For instance Indian women accumulate small amounts until they buy gold that they use as collateral for loans while others buy land in instalments for their long term cash flow generation (Alcala \& Koshy, 2007); in South Africa and India, village savings and loan schemes are common while in Kenya the culture of reliance on children for old age support is rampant (Odundo, 2008). Other challenges are; illiteracy, inexperience with formal financial institutions, low incomes, inadequate government support and lack of pension schemes to join (Uthira \& Manohar, 2009).

\subsubsection{Supply Side Challenges}

Challenges with the supply side of micro pension plans are; the design (whether defined benefit or defined contribution) in the absence of a sponsor, product features since contributions may be volatile, matching sporadic deposits with flexible withdrawals and the risks to be mitigated (investment, inflation and longevity) (Shanker \& Asher, 2009). Other challenges relate to; collection of contributions, payment of benefits, regulation, communication with clients, governance and offering of financial education to the clients (Ross, 2004), lack of expertise in development of the product (McCord \& Buczkowski, 2004), separating fund management and annuity distribution, complexity of administration, high transaction costs and premature withdrawals (Bhattacharya, 2008).

\subsection{Strategies to Address the Challenges to Implementation of Micro-pension Plans}

\subsubsection{Demand Side Strategies}

Key strategies to encourage participation to micro-pension plans are; awareness creation and marketing of the products, portability of the schemes, state guarantees, educating participants and protecting the consumers (Uthira \& Manohar, 2009). Other measures expounded in $\mathrm{Hu} \&$ Stewart (2009) include; providing monetary incentives to participants, encouraging contribution of small frequent amounts and compulsion. Shanker \& Asher (2009) further 
recommend the need to have low or no minimum contribution rates, convenient door to door collection of contributions and insulation of the participants against volatility in investment growth. Bhattacharya (2008) recommend a system with individual accounts where individual's contributions are pooled together in addition to allowing opt outs during periods when participants are not able to contribute.

\subsubsection{Supply Side Policies}

To encourage supply of micro-pension products, providers need to focus on the supply of long-term products so as to earn higher interest, cover inflation and minimize risks (Dullemen \& Bruijn, 2011), supply micro-pension products through multiple agencies, ensuring inexpensive portability and professional management of funds (Uthira \& Manohar, 2009). Other supply side strategies include consumer protection, marketing of the product and capacity building. Hu \& Stewart (2009) suggest other measures as financial education to participants, compulsory participation and centralized administration to lower administrative costs.

\section{Methodology}

The study adopted a variety of methods to answer the research questions. To discern the issues affecting micro-pensions, an exploratory study was conducted in two phases; first focus group interviews that enabled development of a data collection instrument relevant to the Kenyan informal sector context and secondly administering the data collection instruments to a wider group of respondents. This design is advised when it is desired to surface rich data from which valuable insights can be obtained and when literature to develop data collection instruments is limited (Saunders, Lewis \& Thornhill, 2009). To determine the applicability of the models of implementation of the micro-pension arrangements, challenges to implementation and the strategies to enhance application of micro pension arrangements, a questionnaire was developed and administered to Micro Finance Institutions (MFIs) and Savings and Credit Societies (SACCOs) that serve the low income earners in Kenya. To determine the regulatory issues surrounding implementation of micro-pension schemes, the Kenyan retirement benefits laws were reviewed in addition to interviewing key informants from the Retirement benefits Authority in Kenya.

\subsection{Exploratory Research}

In the first stage, three focus group meetings were conducted in line with Krueger and Casey (2000) recommendation that $3-4$ focus group interviews suffice for meaningful insights from interviews. The semi-structured interviews were conducted with 15 informal sector workers; all members of the Kenya National Jua Kali Cooperative Society in Nairobi-Kenya and lasted between 45 minutes and 1 hour. The focus groups had sizes of 6, 4, 5 members with 11 males and 5 females. The participants appeared open and honest as they critically expounded on their natural view of micro-pensions.

\subsection{Questionnaire Survey}

Two questionnaires were administered in the survey. One questionnaire was sent to the informal sector workers who were members of the Jua Kali Federation in Kenya (informal sector business association) while the second questionnaire was sent to the service providers (MFIs and SACCOs) that serve the low income earners).

\subsubsection{Questionnaire to Informal Sector Workers}

This questionnaire was developed with the items got from the exploratory study. This was done to validate and regurgitate the themes from the exploratory study with a wider audience of informal sector workers. The questionnaire had three sections; The first section sought general information relating to gender, age, marital status, highest education level, industry where respondent works, position in employment, years of working, income, whether they save, mode of savings, frequency of saving in a month, whether they would participate in a government supported micro pension scheme, amount and frequency of contribution that they would wish to adopt in a micro pension scheme. The second section of the questionnaire asked the respondents to state the challenges they would experience by participating in a micro-pension plan. The 16 challenges were anchored on a 3 point scale and respondents were asked to mention the extent to which the stated point would be a challenge (1=not at all; $2=$ small extent and 3=very large extent). The third section of the questionnaire asked respondents to indicate the extent to which 14 specific measures would help them join and remain as contributors to a micro pension plan. The items were placed on a 3 point likert scale (1=not at all, 2=small extent and 3=very large extent).

\subsubsection{Questionnaire to Service Providers}

The questionnaire to the service providers had four sections. The first section established the nature of the service providers, the second section listed six factors; anchored on a 5 point scale and asked the respondents to rate the 
extent to which the service providers would derive the benefit if they implemented a micro pension scheme. The third section of the questionnaire sought to determine the challenges that would befall a service provider who offers a micro pension product anchored on a 5 point scale. The fourth section sought to determine the measures that service providers would undertake to operate a sustainable micro pension arrangement.

\subsection{Population and Sampling Frame}

\subsubsection{Informal Sector Workers}

The population for the study consisted of the Kenyan informal workers represented under the Kenya National Jua Kali Cooperative Society (KNJCS) in Kenya. This sampling frame had 197 chapters spread throughout Kenya. Each member association has registered members operating business activities in various sectors. The sampling frame used was last updated on 31 December 2010.

\subsubsection{Service Providers}

The micro-finance institution's sampling frame was obtained from the Association of Micro-finance Institutions in Kenya (AMFI) and had 56 elements. On the other hand, the sampling frame for the Savings and Credit Cooperative Societies was obtained from the SACCO Societies Regulatory Authority (SASRA) and had 145 elements.

\subsection{Sampling Design}

\subsubsection{Informal Sector Participants}

The first sampling frame classified the KNJCS chapters on the basis of 8 provinces in Kenya. Stratified sampling was used to calculate the number of participating chapters from each province. In total 56 chapters participated in the survey. The leaders of the sampled chapters were identified and were requested to provide a list of the businesses in their register. The participants businesses were then randomly drawn from the list. Questionnaires were then administered to employees and owners in the selected businesses. In the event that data was not collected due to inability to identify the sampled businesses, replacement was allowed where the leader of the chapter was requested to identify another business in the locality. This ensured that the response rate was adequate. The target was to identify 1090 Jua Kali Federation informal sector workers drawn from all over Kenya. In total 1083 usable questionnaires were returned representing a $99 \%$ response rate.

\subsubsection{Micro-Finance Institutions and Savings and Credit Cooperative Societies}

Purposive sampling was used to select 35 micro finance institutions and 22 savings and credit cooperative societies from the AMFI and SASRA sampling frames respectively. Purposive sampling ensured that the institutions focus exclusively on serving the low income market. In total, 30 microfinance institutions (86\%) and 20 savings and credit cooperative societies (91\%) responded.

\subsection{Data Analysis}

\subsubsection{Visual Binning}

Visual binning involves collapsing a variable that has a large range of values in to groups (Kinnear, 2008; Larson-Hall, 2010). In visual binning, attributes are segmented into groups with the aim of creating bins that maximize correlation with these attributes. A critical component of the binning process is the enforcement of constraints such as minimum/maximum number of bins, minimum/maximum bin widths and maximum number of observations per bin (Kinnear, 2008). In this study, all the variables that were binned were classified in to 3 categories with cut points being specified at \pm 1 standard deviation. This was done to enhance ease of future replication of the study. The bins used in ranking the challenges were labelled as "Very severe", "less severe” and "not a challenge" while the strategies to enhance application of micro-pension plans were labelled as; "very effective", "less effective" and "not effective".

\subsubsection{Exploratory Factor Analysis (EFA)}

To determine the critical success factors for operation of a micro-pension plan, factor analysis was conducted to reveal the latent variables that cause the manifest variables to covary as recommended in Costello and Orsborne (2005). The software used for exploratory factor analysis was the SPSS version 19. Although SPSS has six factor extraction methods, Fabrigar, Wegener, MacCallum \& Strahan (1999) recommend the maximum Likelihood method when the data is relatively normally distributed. The analysis was run with a varimax 0.5 loading that is recommended for basic social science research. The results were interpreted and named to infer to the nature of the grouping. The mean values were then calculated from the inferred variables to reflect the opinions of the respondents. The views obtained were compared with the opinions expressed by the focus group respondents to facilitate 
discussion of the results.

\section{Findings}

\subsection{Composition of the Sample}

\subsubsection{Informal Sector Participants}

The informal sector workers who participated in the study were mainly male (72\%), 24 - 29 years of age (28.5\%), married (63.9\%), with high school education (42.2\%), in petty trading (14.7\%), with less than 5 years experience (37.8\%), monthly income less than Ksh. 6000 (42.2\%), from Nairobi province (27.1\%) and predominantly employees as opposed to the owners of the informal sector businesses (63.9\%). These statistics are included in table 1.

\subsubsection{Micro-Finance Institutions}

Majority of the MFIs surveyed had been in operation for less than 5 years (36.7\%), had less than 50 employees (53.3\%), had ten or less branches (56.7\%), had 5001-10000 depositors (43.3\%) and less than 5000 borrowers (60\%). These details are included in table 2.

\subsubsection{Savings and Credit Cooperative Societies (SACCOs)}

Majority of the SACCOs surveyed had been in operation for less than 5 years (40\%), had less than 50 employees (60\%), had four or less branches (60\%), and less than 1000 members (55\%). These details are included in table 3.

\subsection{Establishing a Government Supported Micro-pension Plan}

The respondents were affirmative (85.3\%) that they would join a government supported pension plan, 3.4\% would not and $11.3 \%$ were not sure. Asked the monthly amounts that they would be willing to contribute to a government supported pension plan, 25.6\% stated Ksh. 101 - 200, 20.7\% stated more than Ksh. 500, 19.8\% stated Ksh. 401 500, 13.1\% stated Ksh, 201-300, 11.4\% stated less than Ksh. 100 and 9.4\% stated Ksh. 301-400 (table 4). Majority of the respondents who supported a government led micro-pension plan (55\%) indicated that they would prefer to save more than three times in a month. Twenty two percent stated they would wish to save once a month, $16 \%$ twice in a month and $7.2 \%$ three times (table 5).

\subsection{Models for Implementation of a Micro-Pension Scheme}

Interviews with key informants in the retirement benefits industry in Kenya led to the conceptualization of three models for implementation of a micro-pension scheme. The models are centralized nation-wide scheme, Public-Private Partnership and multi-employer models. Each of these models is discussed in turn.

\subsubsection{Centralized Nation-Wide Model}

A centralized nation-wide model involves having one micro-pension that serves all the informal sector workers with or without regional branches. The micro pension scheme is operated by the government on behalf of the members. The key features of the model are; establishment on a defined contribution basis, presence of a custodian, administrator and a fund manager who runs the scheme alternatively these functions can be performed by a department within the organization, the rules for admission, withdrawal and separation are enabled in regulation and are enforced by the government.

The Mbao pension scheme in Kenya is operated by the use of this model. In the Mbao pension scheme, any individual above the age of 18 can join. On attaining the age of 55, the individuals are eligible for pensions. Minimum contributions amount to Ksh. 500 per month but there is no maximum and the contributions can be paid daily, weekly, monthly or quarterly. Although members register with Ksh. 100 to the scheme, no penalties are charged for non-contribution. With no regional branches, members contribute to the scheme through mobile money transfers through the two major mobile phone service providers (Safaricom and Airtel). The funds are invested by service providers appointed by the corporate trustees.

The key advantages of this model are; all contributions from the informal sector workers are pooled together thus creating economies of scale in the investment of funds and there is one reference point for the worker's retirement planning needs. The limitations inherent in the model are; high volume of members may lead to diseconomies of scale in administration, governance systems of the scheme may be inadequate due to the difficulties associated with member's involvement in running the scheme, government bureaucracy may impair the system's efficiency in investment of funds and payment of retirement benefits and given publicity of corrupt practices in government cycles in developing countries, voluntary participation may be difficult. 


\subsubsection{Public-Private Partnership Model}

Under this model, a central pension scheme is maintained by the government but there are public or private agents who provide services to enhance the operations of the pension scheme. The key characteristics of the model are; the scheme is voluntary, defined contribution funded plan, a network of bank branches, microfinance institutions and post offices would be used to collect contributions and interact with participants, an independent centralized record keeping agency is maintained to ensure administrative efficiency and consolidate account statements, each member has a unique number that records contribution savings regardless of the agent used and members of the scheme may be allowed to switch between competing agents. The model thus involves a Public Private Partnership in the provision of the micro-pension products.

A conceptual model for the centralized retirement scheme served by agents or partners is depicted in figure 1 . In the model, the role of the trustees is central. They appoint fund managers, administrators, custodians and the agents (partners). The partners are free to appoint field officers to help market the product. The agents' role is to collect applications and send them to the administrators who open the retirement account for the members. The agents can then receive contributions that they send to the custodians. The responsibility of the fund managers is primarily the investment of funds and must therefore be linked with the custodians. Asked whether they would partner in the implementation of a state led micro pension scheme, 94\% of the MFIs and SACCOs answered in the affirmative. Asked to rate the benefits that would arise if the agent model is implemented to offer micro pensions on a 5 point scale ( 1 = no benefit and 5 = significant benefit), the MFIs and SACCOs noted the benefits included in table 6 as; increased coverage of the pension system, pension plan becomes easy to market, service providers are able to diversify their products, increased outreach for clients, offers flexibility to change agents, contributes to their corporate social responsibility mandate, enhances cross selling of the service providers' products and increases market performance and consequent profitability. Table 7 discloses the most severe challenges of the model as; high administrative costs of operating the scheme, lack of awareness on the operations of the scheme by clients, low level of financial literacy amongst the clients, and absence of a regulatory framework. The less severe challenges are; absence of long-term saving habits amongst clients, high transaction costs charged to the clients and relationship management between different stakeholders. Collection of contributions from clients, payment of benefits to clients and competition with existing products would not pose challenges if the model is implemented.

\subsubsection{Multi-Employer Model}

Under the multi-employer model; employers in a certain industry, profession or cluster create a common pension plan and assume the roles of the sponsors. Such a plan would be formed as a voluntary, defined contribution pension plan with no limit on contributions. The scheme may have regional offices depending on the sector's geographical distribution. Once formed, the rules of the single employer pension schemes may operate in terms of registration of members, general management and compliance requirements. Ideally the model enables pooling together of contributions hence the economies of scale, addresses industry concerns, can take up relatively higher income earners, can allow employer contributions especially in the case of the large SMEs, the schemes are not likely to grow "over size" thus limiting the diseconomies of scale inherent in the centralized systems, the idea is easy to market to various business associations (the Kenya Association of Manufacturers, Public Transport SACCOs and Different Agricultural Sectors), can overcome the problem of adverse publicity as it will be a private sector scheme not public and it makes it easier to educate and influence members since they have common interests.

Challenges with the model would be; some industries are not well organized hence it will only target organized industries, may be affected by industry failure and requires amendment of the existing regulations to define a sponsor as including multi-employers. Additionally, a governance model must be developed to enhance transparency in the appointment of trustees. The governance model must be representative of the varying interests of the multi-employers or sponsors.

\subsection{Micro-Pensions and the Current Pension Laws in Kenya}

Although the RBA Act (law covering retirement benefit schemes in Kenya) is comprehensive and addresses major issues relating to retirement schemes, it does not fully accommodate micro-pensions in the following cases;

Under the RBA Act, a retirement benefit scheme is defined as

"Any scheme or arrangement (other than a contract for life assurance) whether established by a written law for the time being in force or by any other instrument, under which persons are entitled to benefits in the form of payments, determined by age, length of service, amount of earnings or otherwise and payment primarily upon retirement, or upon death, termination of service, or upon the occurrence of 
such other event as may be specified in such written law or other instrument.”

Although the definition captures micro pension schemes indirectly, the inclusion of the themes; benefits determined by length of service, amount of earnings, payment primarily upon retirement and termination of service implies a retirement scheme operated by a sponsor, which may not be the case in micro pensions. Additionally, the rules relating to starting a scheme categorically addresses employer-employee relationships and thus ignores the micro-pension plans.

Section 24 of the RBA Act provides that:

"No scheme, other than a scheme established by a written law shall be registered under this act unless:

the proposed scheme rules adequately protect the rights and interests of the sponsors and members....”

The section categorically excludes micro-pension plans that may not have explicit sponsors. In addition to the above issues; micro-pensions differ significantly with the retirement schemes in the formal environment and so may require a different set of regulation to address matters of; governance (under the current laws micro-pensions can only be managed by corporate trustees which implies that members do not have an opportunity to participate in governance), Investment of funds (micro pensions need investment of funds in less risky situations compared to the sponsor led pension schemes), risk Management (micro pensions are exposed to risks peculiar to them especially relating to contributions, premature withdrawal of benefits, crowding in or out of members and changes in political systems), contribution of funds (the funds contributed in a micro-pension scheme are meagre and irregular), membership (membership is open to all), taxation benefits (under the current pension laws in Kenya, annual pension income is exempt from tax up to Ksh. 240,000. The expected earnings for the informal sector participant is likely to be much lower than this amount.

\subsection{Challenges to Participation in Micro-Pension Plans}

Table 8 discloses the most severe challenges that members would encounter in their attempt to join and remain members of a micro-pension plan as; limitation in income, inaccessibility of funds till retirement, low level of awareness on how pension schemes operate and their consequent complexity and difficulties in claiming benefits on retirement. The lesser severe challenges are; lack of pension schemes to join, less involvement in management of the funds, irregularity in earnings, lack of institutional trust, low rates of return The perception that pension schemes are meant for people in formal employment, failure by employers to remit contributions, age and membership to the current National Social Security Fund were not viewed as impediments.

\subsection{Strategies to Enhance Micro-Pension Schemes}

\subsubsection{Supply Side Strategies}

Table 9 discloses the most effective measures that providers of micro-pension services can apply to enhance micro-pension plans as; increasing enrolment rates to take advantage of economies of scale, maintain an appropriate accounting information system, enhance transparent management, continuous improvement of the pension system to deal with emerging challenges, maintaining an effective risk management system, commitment to serving the low end market, waiving transaction costs for clients, imparting financial education to the participants, government support through co-contribution, developing a unique regulatory framework for micro pensions and branch location near their clients ( rural areas and slums). Having specialized human resources to deal with micro pensions and allowing withdrawals are the least effective strategies.

\subsubsection{Demand Side Strategies}

The results shown in table 10 show the most important strategies to enhance micro-pension plans as; honesty when dealing with members, contribution of small amounts, timely payment of benefits, providing more information on pension schemes, accessibility of the account, frequent statements, payments by mobile money transfer, government co-contribution, portability of the system, maintenance of a portable retirement account. The lesser effective strategies are; contributions by bank transfers, allow withdrawals before retirement and involvement of members in the management of the micro-pension plan. The only factor that is not effective at all was contribution by the employers on behalf of the members.

A factor analysis on the variables approach identified four variables namely; governance, flexibility, design and the contribution mode. Table 11 summarizes these details.

\section{Policy Implications}

Pertinent findings from the study are; 
- Demand for micro-pensions in Kenya is overwhelming with 85.3\% of the possible participants supporting the initiative. Similarly $94 \%$ of the financial service providers would be willing to support such a micro-finance product.

- The models that can be used in the implementation of micro-pension systems are; centralized model, centralized model served by partners or agents in a Public-Private Partnership and the multi-employer micro pension model.

- The current pension laws in Kenya do not fully embrace the micro-pension systems' unique nature.

- The most severe challenges that informal sector participants would face in joining and remaining as members of a micro-pension scheme are; limitation in income, difficulties in accessing funds till retirement, failure to understand how pension plans operate, difficulties in claiming benefits and the inherent lack of involvement in the management of their funds.

- The sternest challenges to the provision of micro-pension services are; high administrative costs, low levels of financial literacy by members, absence of a regulatory framework, absence of savings habits by clients and high transaction costs charged to members.

- The most effective strategies to enhance micro-pension schemes from the perspectives of the service providers are; high enrolment of members, using an appropriate accounting system, transparency in management of the scheme, continuous improvement of processes and developing appropriate risk management systems for micro pensions.

- Governance, flexibility, design and contribution modes are the four critical success factors for the operation of a micro-pension scheme in Kenya

From the findings above; policy makers should;

- Develop micro-pension systems and implement them by use of multiple models. Multiple models will be more accommodative to the diversity of the needs of the informal sector participants as their needs are not homogenous (Choi, 2009).

- Develop a unique regulatory framework to govern micro-pension arrangements. Such regulatory framework should address; registration, governance, investment of funds, risk management, membership, withdrawal of benefits and taxation incentives (Hu \& Stewart, 2009) and should be flexible and simple to enhance development of the micro-pension products.

- Develop micro-pension systems that embrace governance, are flexible to allow joining and quitting and more frequent savings, on contributory design and discourage employer contributions to the schemes. Other issues to be addressed include; marketing of the product, consumer protection, innovation and the establishment of an independent oversight authority for micro-pensions (Uthira \& Manohar, 2009).

\section{Limitations of the Study and Directions for Future Research}

The key limitation of the study lies in the fact that the study was exploratory in nature. As such empirical studies to validate the results were missing and the recommendations of the study came from the respondents. The informal sector participants who were interviewed were all working in businesses affiliated to the Kenya National Jua Kali Federation. This implies that the results cannot be generalized to all informal sector participants in Kenya or elsewhere. It is hoped that future researchers will build on the study to validate the application of the models thought out in the study.

\section{Conclusion}

The design and implementation of micro-pensions could be the missing link in increasing pension coverage in the emerging economies and the Sub-Saharan Africa. The systems should be carefully crafted to address governance, flexibility, the contribution mode and design.

\section{References}

Barrientos, A. (2007). New Strategies for Old-Age Income Security in Low Income Countries. In World Social Security Forum. 10-15 September 2007. Moscow.

Bhattacharya, P. (2008). Micro Pension Plan: Indian Perspective. In Living to 100 and Beyond Symposium January 7 - 9. Orlando, Fla.

Choi, J. (2009). Pension Schemes for the Self Employed in OECD Countries. OECD Social Employment and Migration Working Papers. Paper No. 84. OECD Publishing. 
Costello, A., \& Osborne, J. (2005). Best Practices in Exploratory Factor Analysis: Four Recommendations for Getting Most from Your Analysis. Practical Assessment, Research \& Evaluation, 10(7), 1-10.

Dullemen., C.E., \& Bruijn, J. G. (2011). Pensions for the poor; a case study of micro financing. [Online] Available: http://www.rug.nl/gsg/Research/Conferences/EUmicrofinconf2011/Papers/11A.Bruijn-Dullemen.pdf (15 April 2012)

Government of Kenya. (2011). Kenya Economic Survey - 2011. Kenya National Bureau of Statistics.

Hu, Y., \& Stewart, F. (2009). Pension Coverage and Informal Sector Workers: International Experiences. OECD Working Papers on Insurance and private Pensions. No. 31. OECD Publishing.

Ikiara, G.K., \& Ndungu, N. S. (1999). Adjustment, Employment \& Missing Institutions in Africa. ILO: Geneva.

Kakwani, N., Sun, H., \& Hinz, R. (2006). Old-Age Poverty and Social Pensions in Kenya. International Poverty Center, Working Paper No. 24.

Keizi, L.K. (2006). Barriers to Pension Scheme Participation by Workers in the Informal Economy. [Online] Available: www.rba.go.ke (20 April 2012)

Keizi, L.K. (2007). Can Universal Pension help in Reducing Poverty in Old-Age in Kenya? [Online] Available: www.rba.go.ke (20 April 2012)

Kinner, P.R., \& Gray, C.D. (2008). Psychology Press. [Online] Available: www.psypress/spssmade-simple (20 April 2012)

Krueger, R., \& Casey, M. (2000). A Practical Guide for Applied Research. Sage Publications. Newbury Park: CA.

Larson-Hall, J. (2010). A Guide to Doing Statistics in Second Language Research Using SPSS. Routledge: New York.

McCord, M., \& Buczkowski, G. (2004). Good and Bad Practices in Micro-Insurance.: CARD MBA, the Philippines CGAP Case Study. [Online] Available: www.microfinancegateway.com (15 April 2012)

Odundo, E. (2008). Supervision of Pensions: The Kenyan Experience. [Online] Available: www.rba.go.ke (15 April 2012)

Rajan, S.I. (2003). Old-Age Allowances in Nepal. In Institute for Development Policy and Management International Conference: Staying Poor: Chronic Poverty and Development Policy. Manchester, 7 - 9 April Manchester, IDPM.

Ross, S. G. (2004). Collection of Social Contributions: Current Practices and Critical Issues. In International Conference on Changes in the Structure and Organization of Social Security Administration 18-20 March 2004 Cracow, Poland.

Saunders., M, Lewis., P., \& Thornhill., A. (2009). Research Methods for Business Students. New Jersey: Prentice Hall.

Scheider, F., Buehn, A., \& Montenegro, C.E. (2010). Shadow Economies all over the World. Policy Research Working Paper 5356. World Bank.

Shankar, A., \& Asher, G. (2009). Developing Micro-pensions in India: Issues and Challenges. [Online] Available: http://www.umdcipe.org/conferences/policy_exchanges/conf_papers/Papers/shankar-asher.pdf (20 April 2012)

Stewart, F., \& Yermo J. (2009). Pensions in Africa. OECD Publishing.

Uthira, D., \& Manohar, H.L. (2009). Economic Implications and Sustainability of Micro-pensions in the Era of Pension Reforms in India. International Research Journal of Finance and Economics, 24(2009), 36-48.

Winters, L.A. (2002). Trade Liberalization and Poverty: What are the Links? The World Economy, 25(9), $1337-1367$. http://dx.doi.org/10.1111\%2F1467-9701.00495

World Bank. (2006). The Informal Sector: What Is It, Why Do We Care, and How Do We Measure It? [Online] Available: http://siteresources.worldbank.org/INTLAC/Resources/CH1.pdf (15 April 2012) 
Table 1. Demographic composition of informal sector participants

\begin{tabular}{|c|c|c|c|}
\hline Variable & & $\mathbf{N}$ & $\%$ \\
\hline \multirow[t]{3}{*}{ Gender } & Male & 780 & 72 \\
\hline & Female & 303 & 28 \\
\hline & Total & 1083 & 100 \\
\hline \multirow[t]{7}{*}{ Age } & 18-23 years & 171 & 15.8 \\
\hline & $24-29$ & 309 & 28.5 \\
\hline & $30-35$ & 248 & 22.9 \\
\hline & $36-41$ & 150 & 13.9 \\
\hline & $42-47$ & 108 & 10.0 \\
\hline & $48-53$ & 59 & 5.4 \\
\hline & Total & 1083 & 100 \\
\hline \multirow[t]{5}{*}{ Marital Status } & Single & 324 & 29.9 \\
\hline & Married & 692 & 63.9 \\
\hline & Separated or divorced & 37 & 3.4 \\
\hline & Widowed & 30 & 2.8 \\
\hline & & 1083 & 100 \\
\hline \multirow[t]{4}{*}{ Highest Education Level } & Primary School & 363 & 33.5 \\
\hline & High School & 457 & 42.2 \\
\hline & College, technical or polytechnic & 223 & 20.6 \\
\hline & University & 40 & 3.7 \\
\hline \multirow[t]{6}{*}{ Years of Experience } & $<5$ years & 409 & 37.8 \\
\hline & $6-10$ & 374 & 34.5 \\
\hline & $11-15$ & 139 & 12.8 \\
\hline & $16-20$ & 91 & 8.4 \\
\hline & $20>$ & 70 & 6.5 \\
\hline & Total & 1083 & 100 \\
\hline \multirow[t]{3}{*}{ Position in Business } & Owner & 392 & 36.2 \\
\hline & Employee & 691 & 63.8 \\
\hline & & 1083 & 100 \\
\hline \multirow[t]{7}{*}{ Monthly Income } & $<6,000$ Ksh. & 457 & 42.2 \\
\hline & $6,001-12,000$ & 246 & 22.7 \\
\hline & $12,001-18,000$ & 46 & 4.2 \\
\hline & $18,001-24,000$ & 197 & 18.2 \\
\hline & $24,001-30,000$ & 59 & 5.4 \\
\hline & $>30,000$ & 78 & 7.2 \\
\hline & Total & 1083 & 100 \\
\hline \multirow[t]{15}{*}{ Industry } & Textile & 80 & 7.4 \\
\hline & Woodwork & 99 & 9.1 \\
\hline & Metal work & 45 & 4.2 \\
\hline & Motor vehicle repair & 139 & 12.8 \\
\hline & Food processing & 82 & 7.6 \\
\hline & Electrical & 30 & 2.8 \\
\hline & Transport & 103 & 9.5 \\
\hline & Handicraft & 44 & 4.1 \\
\hline & Leatherwork & 29 & 2.7 \\
\hline & Merchandising & 117 & 10.8 \\
\hline & Petty trading & 159 & 14.7 \\
\hline & Welding & 88 & 8.1 \\
\hline & Bicycle or motor cycle repair & 31 & 2.9 \\
\hline & Salon or barber shop & 37 & 3.4 \\
\hline & Total & 1083 & 100 \\
\hline
\end{tabular}


Table 2. Characteristics of the MFI sample

\begin{tabular}{|c|c|c|c|}
\hline & & $\mathbf{N}$ & $\%$ \\
\hline \multirow[t]{6}{*}{ Years in operation } & $<5$ years & 11 & 36.7 \\
\hline & $6-10$ & 6 & 20.0 \\
\hline & $11-15$ & 6 & 20.0 \\
\hline & $16-20$ & 3 & 10.0 \\
\hline & $>20$ & 4 & 13.3 \\
\hline & & 30 & 100 \\
\hline \multirow[t]{6}{*}{ Number of employees } & $<50$ & 16 & 53.3 \\
\hline & $51-100$ & 6 & 20 \\
\hline & $101-150$ & 4 & 13.3 \\
\hline & $151-200$ & 1 & 3.4 \\
\hline & $>200$ & 3 & 10.0 \\
\hline & Total & 30 & 100 \\
\hline \multirow[t]{5}{*}{ Number of Branches } & $1-10$ & 17 & 56.7 \\
\hline & $11-20$ & 10 & 33.3 \\
\hline & $21-30$ & 1 & 3.3 \\
\hline & 31 or more & 2 & 6.7 \\
\hline & Total & 30 & 100 \\
\hline \multirow[t]{5}{*}{ Number of Depositors } & $<5000$ & 8 & 26.7 \\
\hline & 5001-10000 & 13 & 43.3 \\
\hline & $10001-15000$ & 3 & 10.0 \\
\hline & More than 15000 & 6 & 20.0 \\
\hline & Total & 30 & 100 \\
\hline \multirow[t]{5}{*}{ Number of Borrowers } & $<5000$ & 18 & 60.0 \\
\hline & 5001-10000 & 5 & 16.7 \\
\hline & $10001-15000$ & 3 & 10.0 \\
\hline & More than 15000 & 4 & 13.3 \\
\hline & Total & 30 & 100 \\
\hline
\end{tabular}


Table 3. Characteristics of the sacco sample

\begin{tabular}{|c|c|c|c|}
\hline Variable & & $\mathbf{N}$ & \\
\hline \multirow[t]{6}{*}{ Number of years in operation } & 5 or less & 4 & 20 \\
\hline & $6-10$ & 2 & 10 \\
\hline & $11-15$ & 10 & 50 \\
\hline & $16-20$ & 3 & 15 \\
\hline & More than 20 & $\underline{1}$ & $\underline{5}$ \\
\hline & TOTAL & 20 & 100 \\
\hline \multirow[t]{4}{*}{ Number of Employees } & 50 or less & 12 & 60 \\
\hline & $51-100$ & 5 & 25 \\
\hline & $101-150$ & 3 & 15 \\
\hline & TOTAL & 20 & 100 \\
\hline \multicolumn{4}{|l|}{ Number of Branches } \\
\hline & $1-4$ & 12 & 60 \\
\hline & $5-8$ & 5 & 25 \\
\hline & $9-12$ & 2 & 10 \\
\hline & More than 12 & 1 & 5 \\
\hline & TOTAL & 20 & 100 \\
\hline \multirow[t]{5}{*}{ Number of Members } & Less than 1000 & 11 & 55 \\
\hline & $1001-2000$ & 6 & 30 \\
\hline & $2001-3000$ & 2 & 10 \\
\hline & More than 3000 & 1 & 5 \\
\hline & TOTAL & 20 & 100 \\
\hline
\end{tabular}

Table 4. Amount to contribute to a government supported pension plan

\begin{tabular}{lll}
\hline Monthly Amount Ksh. & Frequency & Percent \\
\hline$<100$ & 123 & 11.4 \\
$101-200$ & 277 & 25.6 \\
$201-300$ & 142 & 13.1 \\
$301-400$ & 102 & 9.4 \\
$401-500$ & 214 & 19.8 \\
$>500$ & 225 & 20.7 \\
& $\mathbf{1 0 8 3}$ & $\mathbf{1 0 0}$ \\
\hline
\end{tabular}

Table 4 shows that majority of the population (25.6\%) prefer to contribute between Ksh. 101-200 in a government supported micro-pension plan. 
Table 5. Frequency of saving

\begin{tabular}{lll}
\hline $\begin{array}{l}\text { Number of times to save in a } \\
\text { month }\end{array}$ & Frequency & Percent \\
\hline Once & 238 & 22 \\
Twice & 173 & 16 \\
Thrice & 76 & 7 \\
More than 3 times & 596 & 55 \\
Total & 1083 & 100 \\
\hline
\end{tabular}

Table 5 shows that majority of the respondents (55\%) would prefer to save more than 3 times every month in a micro-pension scheme.

Table 6. Advantages of the partner-agent model of micropension plan

\begin{tabular}{lccc}
\hline & $\mathrm{N}$ & Mean & Std. Deviation \\
\hline Increases the coverage of the pension system & 50 & 4.62 & 0.365 \\
The pension plan becomes easy to market & 50 & 4.12 & 0.652 \\
Service providers will diversify their products & 50 & 4.03 & .964 \\
Will increase their outreach to the clients & 50 & 3.97 & .890 \\
The model offers flexibility to change the agents & 50 & 3.95 & 0.875 \\
Contributes to the corporate social responsibility mandate & 50 & 3.90 & 1.269 \\
Will enhance cross selling of the MFI products & 50 & 3.77 & .971 \\
Increased market performance & 50 & 3.60 & 1.133 \\
Increase in profitability & 50 & 3.30 & 1.055 \\
\hline
\end{tabular}

Table 6 shows the perceptions of the service providers with regard to the benefits that would be gained if private micro service providers were to partner with the government in offering micro-pension services

Table 7. Challenges of the partner model

\begin{tabular}{|c|c|c|c|}
\hline & $\mathbf{N}$ & Mean & Bin Label \\
\hline High administrative costs of implementing the scheme & 50 & 3.87 & Very severe \\
\hline Awareness of the operations of the scheme by the clients & 50 & 3.83 & Very severe \\
\hline Low financial literacy amongst the clients & 50 & 3.77 & Very severe \\
\hline Absence of a regulatory framework & 50 & 3.70 & Very severe \\
\hline The clients do not have a long-term savings habit & 50 & 3.53 & Less severe \\
\hline High transaction costs of implementing the scheme & 50 & 3.50 & Less severe \\
\hline Relationship management with stakeholders (RBA, fund administrators) & 50 & 3.23 & Less severe \\
\hline Collection of contributions & 50 & 3.17 & Not a challenge \\
\hline Payment of benefits & 50 & 3.03 & Not a challenge \\
\hline Competition with existing products & 50 & 2.50 & Not a challenge \\
\hline
\end{tabular}

Table 7 discusses the problems that would be encountered in the event that private financial service providers would have to deal with if they partnered with the government to offer micro-pension services. The factors are categorized by use of visual binning at \pm 1 standard deviation. 
Table 8. Challenges to participation in a micro-pension scheme

\begin{tabular}{lccl}
\hline & $\mathbf{N}$ & Mean Bin Label \\
\hline Limitation in income & 1083 & 2.33 Very severe \\
The money will not be accessible to me until retirement & 1083 & 2.23 Very severe \\
I do not know how pension schemes operate & 1083 & 2.18 Very severe \\
Pension schemes are complex and involving & 1083 & 2.17 Very severe \\
It will be difficult to claim my benefits when I retire & 1083 & 2.16 Very severe \\
Lack of a pension scheme which I can join & 1083 & 2.14 Less severe \\
I will not be involved in the direct management of my money & 1083 & 2.12 Less severe \\
My income is not regular & 1083 & 2.08 Less severe \\
I would not trust anyone with my retirement money & 1083 & 2.07 Less severe \\
Rate of return is too low & 1083 & 2.01 Less severe \\
Pension schemes are for those people in formal employment & 1083 & 1.88 Not a challenge \\
My employer may not submit my contributions & 1083 & 1.85 Not a challenge \\
I do not trust my employer to submit my contributions & 1083 & 1.84 Not a challenge \\
I see no benefit of joining a pension scheme & 1083 & 1.78 Not a challenge \\
I am still too young & 1083 & 1.55 Not a challenge \\
I am already a member of NSSF & 1083 & 1.40 Not a challenge
\end{tabular}

Table 8 discloses the problems that participants would go through as members of a micro-pension scheme. The factors are categorized by use of visual binning at \pm 1 standard deviation.

Table 9. Supply side strategies

\begin{tabular}{lll} 
& N & Mean Bin Label \\
\hline High enrolment to lower the administrative costs & 50 & 4.50 Very Effective \\
Maintaining an effective accounting system & 50 & 4.50 Very Effective \\
Maintaining an effective risk management system & 50 & 4.33 Very Effective \\
Transparent management & 50 & 4.27 Very Effective \\
Continuous adaptation and innovation of processes & 50 & 4.27 Very Effective \\
Commitment in serving the low end market & 50 & 4.23 Very Effective \\
Waiving transaction costs for clients & 50 & 4.20 Very Effective \\
Enhance financial literacy amongst the clients & 50 & 4.20 Very effective \\
Customizing micro pension product - easy payments by customers & 50 & 4.17 Less Effective \\
Co-contribution by the government & 50 & 4.17 Less Effective \\
Have a governing law or regulation articulating the unique nature of a micro-pension & 50 & 4.00 Less Effective \\
Location of branches near clients (sometimes rural and slum areas) & 50 & 4.00 Less Effective \\
Having specialized human resource to deal with the sector & 50 & 3.47 Not Effective \\
Allowing withdrawals from the scheme & 50 & 3.43 Not Effective \\
\hline
\end{tabular}

Table 9 tabulates the measures that suppliers of micro-financial services can take to enhance success of micro-pension schemes. The factors are categorized by use of visual binning at \pm 1 standard deviation. 
Table 10. Demand side strategies to enhance micro-pensions

\begin{tabular}{lll}
\hline & $\mathbf{N}$ & Mean Bin Label \\
\hline Pension schemes should be honest while dealing with members & 1083 & 2.87 Very Effective \\
The system should allow contribution of small amounts & 1083 & 2.84 Very Effective \\
Ensure that retirement benefits are paid on time & 1083 & 2.83 Very Effective \\
Give more information on pension schemes and retirement issues in general & 1083 & 2.79 Very Effective \\
I should be able to access my account details on phone for instance by SMS or calling the & 1083 & 2.78 Very Effective \\
pension scheme administrators & 1083 & 2.78 Very Effective \\
Be provided with a frequent statement of contributions and interest & 1083 & 2.77 Very Effective \\
The system should allow contributions to be paid by Mobile money transfer & 1083 & 2.73 Very Effective \\
The government should support the system by making additional contributions & 1083 & 2.64 Very Effective \\
I should be able to "move” with my pension benefits if I change jobs & 1083 & 2.63 Very Effective \\
Have a personal retirement account similar to a bank account & 1083 & 2.53 Less Effective \\
The system should allow contributions to be paid by bank transfers and deposits & 1082 & 2.52 Less Effective \\
Allow withdrawal of some amounts before retirement & 1083 & 2.47 Less Effective \\
I am more involved in management of the pension scheme & 1083 & 1.98 Not Effective \\
Encourage employer to deduct pension contribution from my pay
\end{tabular}

Table 10 lists the strategies that can be applied to enhance success of a micro-pension scheme from the participant's views. The factors are categorized by use of visual binning at \pm 1 standard deviation.

Table 11. Rotated component matrix ${ }^{\mathrm{a}}$

\begin{tabular}{|c|c|c|c|c|}
\hline & \multicolumn{4}{|c|}{ Component } \\
\hline & Governance & Flexibility & Design & Contribution Mode \\
\hline Honesty & .729 & & & \\
\hline Timely Payment & .773 & & & \\
\hline Allow Withdrawal & .374 & & & \\
\hline More Information & .341 & & & \\
\hline Management Involvement & 715 & & & \\
\hline Retirement Account & & & .743 & \\
\hline Move With Benefits & & & .691 & \\
\hline Allow small contributions & & & .713 & \\
\hline Frequent Statements & & .343 & & \\
\hline Mobile Accessibility & & .647 & & \\
\hline Government Support & & .583 & & \\
\hline Mobile Payment & & .767 & & \\
\hline Bank Payment & & & & .511 \\
\hline Salary Deduction & & & & .748 \\
\hline
\end{tabular}




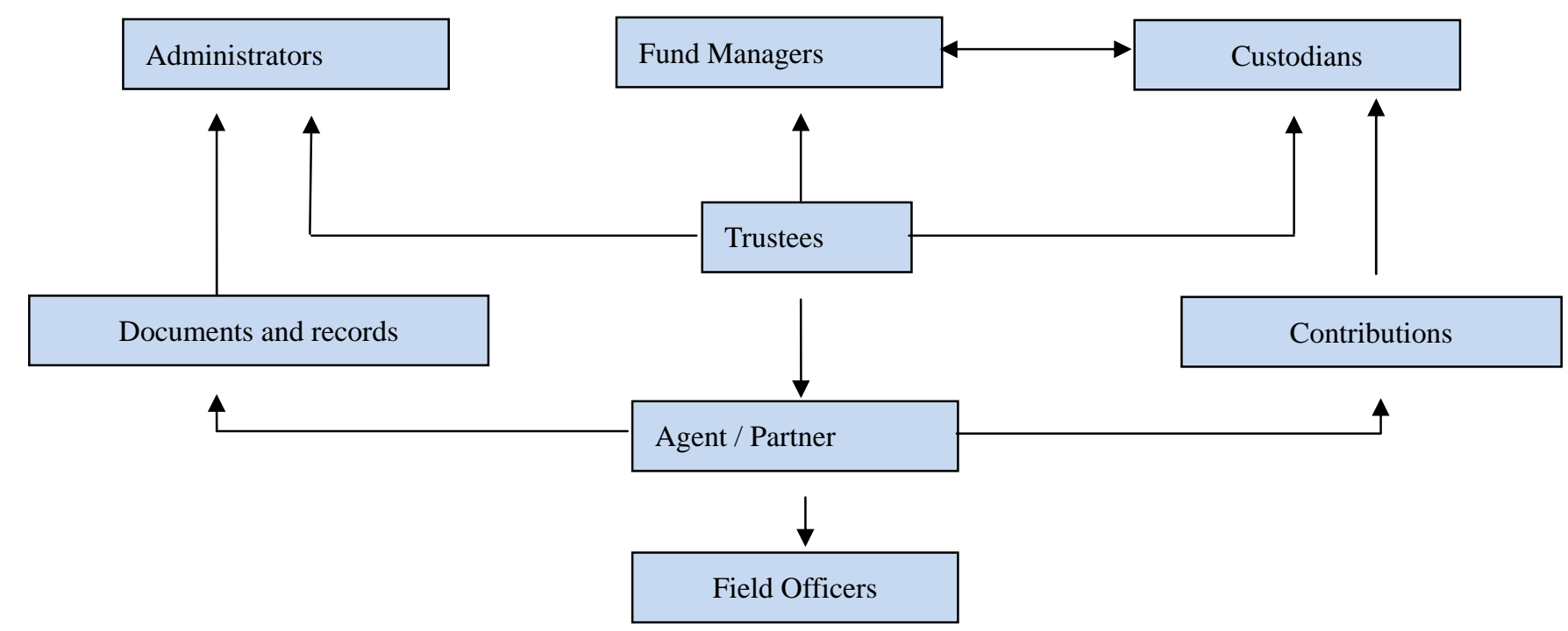

Figure 1. Conceptual model for the Partner-Agent (PPP) Model of Micropension Plan

Figure 1 conceptualizes the partner agent model that is enabled by the government and the private micro-finance service providers and agents help in the recruitment of members through their appointed field officers. Trustees are central to the model. These trustees represent the interests of the government through the pension regulator, the private sector and members of the scheme. The role of the agents (post offices, micro-finance institutions and other micro-financial service providers) is to recruit members and collect identification documents and contributions. Contributions are remitted to the custodians while documents are remitted to the administrators who are appointed by the trustees. Investment of funds is done by the fund managers. 